Article

\title{
A Time-Course Study on a Food Contact Material (FCM)-Certified Coating Based on Titanium Oxide Deposited onto Aluminum
}

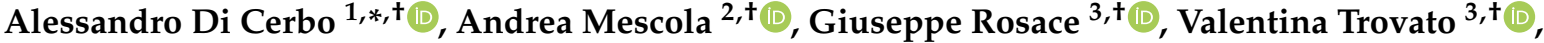 \\ Roberto Canton ${ }^{4}\left(\mathbb{D}\right.$, Ramona Iseppi ${ }^{5}{ }^{(D}$, Roberta Stocchi ${ }^{1}$, Shakira Ghazanfar $\left.{ }^{6}{ }^{(}\right)$, Stefano Rea ${ }^{1, \ddagger}$, \\ Anna Rita Loschi ${ }^{1, \ddagger}$ and Carla Sabia ${ }^{5, \ddagger \mathbb{B}}$
}

check for

updates

Citation: Di Cerbo, A.; Mescola, A.;

Rosace, G.; Trovato, V.; Canton, R.;

Iseppi, R.; Stocchi, R.; Ghazanfar, S.

Rea, S.; Loschi, A.R.; et al. A

Time-Course Study on a Food

Contact Material (FCM)-Certified

Coating Based on Titanium Oxide

Deposited onto Aluminum. Biology

2022, 11, 97. https://doi.org/

10.3390/biology11010097

Academic Editor: Joana Barbosa

Received: 17 December 2021

Accepted: 6 January 2022

Published: 8 January 2022

Publisher's Note: MDPI stays neutral with regard to jurisdictional claims in published maps and institutional affiliations.

Copyright: (C) 2022 by the authors. Licensee MDPI, Basel, Switzerland. This article is an open access article distributed under the terms and conditions of the Creative Commons Attribution (CC BY) license (https:// creativecommons.org/licenses/by/ $4.0 /)$
1 School of Biosciences and Veterinary Medicine, University of Camerino, 62024 Matelica, Italy; roberta.stocchi@unicam.it (R.S.); stefano.rea@unicam.it (S.R.); annarita.loschi@unicam.it (A.R.L.)

2 CNR-Nanoscience Institute-S3, 41125 Modena, Italy; andrea.mescola@nano.cnr.it

3 Department of Engineering and Applied Sciences, University of Bergamo, 24044 Dalmine, Italy; giuseppe.rosace@unibg.it (G.R.); valentina.trovato@unibg.it (V.T.)

4 Moma Nanotech S.r.l., 20861 Brugherio, Italy; canton@nanotech.it

5 Department of Life Sciences, University of Modena and Reggio Emilia, 41125 Modena, Italy; ramona.iseppi@unimore.it (R.I.); carla.sabia@unimore.it (C.S.)

6 National Agricultural Research Centre, National Institute of Genomics and Agriculture Biotechnology (NIGAB), Park Road, Islamabad 45500, Pakistan; shakira_akmal@yahoo.com

* Correspondence: alessandro.dicerbo@unicam.it; Tel.: +39-0737-403466

$+\quad$ These authors contributed equally.

$\ddagger$ Shared senior co-authorship.

Simple Summary: In this study, we confirm the bactericidal effect of a special anodizing method, based on $\mathrm{TiO}_{2}$ nanoparticles (DURALTI ${ }^{\circledR}$ ) deposited on aluminum disks with different roughness and subjected to two sanitizing treatments, and, consequently, performing a time-course evaluation against both Gram-negative and Gram-positive bacteria. DURALTI ${ }^{\circledR}$ coating already confirmed its ability to induce a 4-logarithmic decrease (from $10^{6}$ to $10^{2} \mathrm{CFU} / \mathrm{mL}$ ) after $6 \mathrm{~h}$. Once each sanitizing treatment was applied, an overall bacterial inhibition occurred in a time ranging from $15^{\prime \prime}$ to $1^{\prime}$.

Abstract: Aluminum is the second most widely used metal worldwide. It is present as an additive in cosmetics, pharmaceuticals, food, and food contact materials (FCM). In this study, we confirm the bactericidal effect of a special anodizing method, based on $\mathrm{TiO}_{2}$ nanoparticles (DURALTI ${ }^{\circledR}$ ) deposited on aluminum disks with different roughness and subjected to two sanitizing treatments: UV and alcohol 70\%. Consequently, we perform a time-course evaluation against both Gram-negative and Gram-positive bacteria to better frame the time required to achieve the best result. Approximately $10^{6}$ CFU/mL of Escherichia coli ATCC 25922; Salmonella Typhimurium ATCC 1402; Yersinia enterocolitica ATCC 9610; Pseudomonas aeruginosa ATCC 27588; Staphylococcus aureus ATCC 6538; Enterococcus faecalis ATCC 29212; Bacillus cereus ATCC 14579 and Listeria monocytogenes NCTT 10888 were inoculated onto each aluminum surface and challenged with UV and alcohol 70\% at $0,15^{\prime \prime}, 30^{\prime \prime}, 1^{\prime}, 5^{\prime}, 15^{\prime}, 30^{\prime}$, $1,2,4$ and 6 h. DURALTI ${ }^{\circledR}$ coating already confirmed its ability to induce a 4-logarithmic decrease (from $10^{6}$ to $10^{2} \mathrm{CFU} / \mathrm{mL}$ ) after $6 \mathrm{~h}$. Once each sanitizing treatment was applied, an overall bacterial inhibition occurred in a time ranging from $15^{\prime \prime}$ to $1^{\prime}$. The results are innovative in terms of preventing microbial adhesion and growth in the food industry.

Keywords: aluminum; food contact materials; sanitizing treatments; $\mathrm{TiO}_{2}$; bacterial inhibition

\section{Introduction}

Aluminum is the second most widely used metal worldwide, owing to its castability, plasticity, low melting point and density, heat conductivity and oxidative passivation [1] 
It is present as an additive (as itself or derivatives) in cosmetics [1], pharmaceuticals ( $\mathrm{pH}$ regulation of heartburn medicine, and vaccine adjuvants) [2], food of both plant and animal origins (vegetables, milk products, sausages and seafood) [3-5] as well as food contact materials (FCM) (beverage and food cans, coffee pots, cooking and kitchen utensils, coffee capsules and household aluminum foil) [6-9].

In 2008, the European Food Safety Authority (EFSA) set the provisional tolerable weekly intake of aluminum to $1 \mathrm{mg} \mathrm{kg}^{-1}$ body weight [6], while Regulation (EC) No. 1333/2008 sought to regularize food additive use, including aluminum, along with their maximum level [10]. Moreover, in 2013, the Council of Europe set the maximal amount of metal ions (mg), including aluminum, that can migrate from an FCM surface to the food ( $\mathrm{kg}$ ), i.e., $5.00 \mathrm{mg} / \mathrm{kg}$ foodstuff [11]. Nevertheless, recent toxicological studies report that the daily intake of aluminum derived from food ranges from 3.4 to $9 \mathrm{mg} /$ day, thus continuing to pose a serious concern to public health due to an overdosage [1,12]. In fact, several reports highlight the toxic role of aluminum, including, but not limited to, the induction of oxidative stress [13], organ inflammation [14], immunosuppression [13], protein denaturation and transformation [15], apoptosis [13] and endocrine disruption [16].

Nowadays, the use of aluminum and alloys as an FCM is discussed in Regulation (EC)1935/2004, which specifically deals with materials and articles intended to come into contact with food [17].

In addition to aluminum intoxication, another risk for consumers derived from FCM is microbial contamination, and the consequent spoilage of food with repercussions also on health, sensory and nutritional features [18].

In the last decade, nanotechnology offered several opportunities to significantly reduce the release of metal ions, the use of corrosive sanitizing agents and the microbial contamination preserving, at the same time, both food quality and the consumer's health [18-23].

In this sense, many techniques, such as physical vapor deposition, plasma-enhanced chemical vapor deposition, atmospheric-pressure plasma deposition, sol-gel and anodizing, have been proposed to facilitate the deposition of a coating onto FCM, making them antibacterial, non-cytotoxic and easy to clean at the same time [24].

In particular, anodizing is typical of aluminum-based materials that, once placed in an electrolytic cell with aqueous sulfuric acid acting as an electrolyte, form a film of aluminum oxide of $0.08 \mu \mathrm{m}$ covered by a porous layer of up to $25 \mu \mathrm{m}$, according to the equation: $2 \mathrm{Al}+3 \mathrm{H}_{2} \mathrm{O} \rightarrow \mathrm{Al}_{2} \mathrm{O}_{3}+6 \mathrm{H}^{+}+6 \mathrm{e}^{-}$. To date, nanocomposites (nanoparticles, clay and silicate nanoplatelets, carbon nanotubes, starch nanocrystals and cellulose-based nanofibers) are the most used materials in the food industry, for packaging and coating purposes [25-28]. Owing to their intrinsic photocatalytic activity or the release of metallic ions, silver [29-31], golden [32-34] and metal oxide $\left(\mathrm{TiO}_{2}, \mathrm{ZnO}, \mathrm{Fe}_{3} \mathrm{O}_{4}, \mathrm{CuO}, \mathrm{MgO}\right)[8,35-39]$ nanoparticles showed the most effective and reliable biocidal activity against both Gram-positive and Gram-negative bacteria via ROS generation [40]. In particular, $\mathrm{TiO}_{2}$, a thermally stable, biocompatible, semiconducting transition metal, endowed with good resistance to chemical erosion and a wide bandgap of $3.2 \mathrm{eV}$, has also been extensively used for other purposes, including deodorant and self-cleaning [41-44].

In this study, we aimed to confirm the bactericidal effect of a special anodizing method based on $\mathrm{TiO}_{2}$ nanoparticles deposited onto aluminum disks with different roughness and subjected to two sanitizing treatments, and, consequently, performing a time-course evaluation to better frame the time required to achieve the best result.

\section{Materials and Methods}

\subsection{Samples and Coating}

Four hundred and thirty-two round-shaped aluminum disks with a $5 \mathrm{~cm}$ diameter, $0.5 \mathrm{~cm}$ thickness and three different surface roughness, $\left(R_{a}\right) 0.25 \pm 0.02 \mu \mathrm{m}(\mathrm{R} 0.25, n=144)$, $0.5 \pm 0.03 \mu \mathrm{m}(\mathrm{R} 0.5, n=144)$ and $1 \pm 0.06 \mu \mathrm{m}(\mathrm{R} 1, n=144)$, were used in this study. A total of 216 disks were coated with a special anodizing based on $\mathrm{Al}_{2} \mathrm{O}_{3}-\mathrm{TiO}_{2}$, named DURALTI $^{\circledR}$ [45], approved for food contact according to the FCM certification, while the 
remaining 216 disks were left uncoated. DURALTI ${ }^{\circledR}$ is characterized by a hardness of $500 \mathrm{HV}$, a low abrasion index ( $<10 \mathrm{mg}$ of weight loss) according to the ASTM D 4060 standard [46], a static friction coefficient of 0.2 , and a dynamic friction coefficient of 0.15 , as well as strong resistance corrosion (almost $1000 \mathrm{~h}$ ) according to the ASTM B 117 standard [47]. Furthermore, it is compliant with Regulation (EC)1935/2004 [17], and with DIN 10,531 [48] and UNI 11,460 [49] standards for the lack of lead and nickel release in the production and dispense of hot beverages from hot beverage appliances [48].

\subsection{Microbiological Analysis}

Gram-negative (Escherichia coli ATCC 25922, Salmonella Typhimurium ATCC 1402, Yersinia enterocolitica ATCC 9610, and Pseudomonas aeruginosa ATCC 27588) and Grampositive (Staphylococcus aureus ATCC 6538, Enterococcus faecalis ATCC 29212, Bacillus cereus ATCC 14579 and Listeria monocytogenes NCTT 10888) strains were purchased from LGC Standards S.r.l. (Sesto San Giovanni, Milan, Italy). Subsequently, they were grown in tryptic soy broth (TSB, bioMérieux, Florence, Italy), incubated at $37^{\circ} \mathrm{C}$ for $24 \mathrm{~h}$ and activated by two successive transfers.

\subsection{Inoculum Preparation}

For each strain, $100 \mu \mathrm{L}$ of the overnight culture was transferred into $10 \mathrm{~mL}$ of tryptic soy broth (TSB, Oxoid, Milan, Italy) and incubated at $37^{\circ} \mathrm{C}$ with an oscillating speed of $150 \mathrm{rpm}$. After $5 \mathrm{~h}$, the optical density (OD) was determined at $600 \mathrm{~nm}$ using a microtiter plate reader (Sunrise ${ }^{\mathrm{TM}}$, Tecan Trading AG, Männedorf, Switzerland), and the viable cell count was determined by spreading on tryptic soy agar (TSA, Oxoid, Milan, Italy) plates. Approximately $10^{6} \mathrm{CFU} / \mathrm{mL}$ of each strain was inoculated onto each aluminum surface, according to the procedure previously described [21].

\subsection{FTIR Characterization}

Both uncoated and DURALTI ${ }^{\circledR}$-coated aluminum disks were characterized by Fourier transform infrared spectroscopy (FTIR). FTIR spectra were recorded with a Thermo Avatar 370 , equipped with an attenuated total reflection (ATR) device using a diamond crystal as an internal reflectance element. Spectra were acquired at room temperature in the range from 4000 to $530 \mathrm{~cm}^{-1}$, with 32 scans and a resolution of $4 \mathrm{~cm}^{-1}$.

\subsection{Time-Course Assay, Sanitizing Procedures and Surface Swabbing}

A total of 27 coated and 27 uncoated disks were used for each bacterial strain: for each roughness, 9 coated and 9 uncoated disks were used for control $(n=3)$, UV (UVC, $253 \mathrm{~nm}$, $n=3)$ and alcohol $70 \%(n=3)$ treatment.

Each aluminum surface was swabbed 10 times vertically and horizontally, using a moistened sterile cotton (Incofar, Modena, Italy) at different times $\left(0,15^{\prime \prime}, 30^{\prime \prime}, 1^{\prime}, 5^{\prime}, 15^{\prime}\right.$, $30^{\prime}, 1,2,4$ and $6 \mathrm{~h}$ ).

Then, the cotton head was aseptically broken off and placed in a tube with $1 \mathrm{~mL}$ of sterile saline $0.9 \%$ solution and vortexed for $1^{\prime}$. Serial tenfold dilutions were spread onto selective agar plates and the viable cells were counted after incubation at $37^{\circ} \mathrm{C}$ for $24 \mathrm{~h}$.

\subsection{Environmental Scanning Microscopy Analysis (ESEM)}

An ESEM Quanta-200 (ThermoFisher Scientific, Rodano, Italy) connected with a microanalysis system X-EDS Oxford INCA-350 was used to obtain micrographs and spectra of each roughness, both on coated and uncoated aluminum disks.

Each sample was mounted on an aluminum stub via double-sided adhesive tape and observed without sputtering at a high vacuum $\left(\approx 10^{-5}\right.$ Torr $)$, with an accelerating voltage of $25 \mathrm{kV}$, working distance between 11 and $12 \mathrm{~mm}$, spot size $4 \mu \mathrm{m}$ and standard acquisition resolution $1024 \times 943$ pixels.

Micrographs at $500 \times$ original magnifications were acquired while sample areas of $\sim 300 \mu \mathrm{m} \times 300 \mu \mathrm{m}$ were being investigated. 


\subsection{Contact Angle (CA) Measurements}

Static CA values of uncoated and DURALTI ${ }^{\circledR}$-coated aluminum disks were measured by a homemade instrument equipped with a high-speed CCD camera.

The used equipment allows the determination of CA, with a precision of $\pm 1^{\circ}$, by taking images at frequencies as high as $200 \mathrm{~Hz}$, starting within a few tens of milliseconds after the deposition of the drop. All measurements were performed under an ambient atmosphere at room temperature and common moisture of $\mathrm{RH}=40 \pm 5 \%$. Double-distilled water with a conductivity less than $10^{-6} \mathrm{~S} \cdot \mathrm{m}^{-1}$ at $25^{\circ} \mathrm{C}$ was used for cleaning all materials and contact angle measurements. Before all measurements, uncoated and coated samples were cleaned with such a water, thoroughly rinsed with ethanol to minimize any potential surface contamination, and finally dried for $24 \mathrm{~h}$ at least. A drop of high purity distilled water was located on the surface of the samples, and the image of the droplet was recorded after $10^{\prime \prime}$ with the CCD camera. The drop volume was chosen within a range for which the CA did not change with the variation of the volume $(4 \pm 0.5 \mu \mathrm{L})$.

The CA values were determined using an image analysis software (ImageJ 1.46r, Wayne Rasband, National Institutes of Health, Bethesda, Maryland, USA). According to other research findings that confirmed the close correlation between the surface topography and the measured angles, the final CA values were obtained by averaging measured data at ten randomly selected points [50,51]. For each sample with the same surfaces roughness, the $C A$ change $\left(C A_{\text {change }}\right)$ between uncoated and coated disks was obtained by the following Equation (1):

$$
C A_{\text {change }}(\%)=\frac{C A_{\text {coated }}-C A_{\text {uncoated }}}{C A_{\text {uncoated }}} \times 100
$$

where $C A_{\text {coated }}$ is the CA of the coated surface and $C A_{\text {uncoated }}$ is the CA of the uncoated surface.

\section{Results}

\subsection{FTIR Characterization}

FTIR spectra of uncoated and DURALTI ${ }^{\circledR}$-coated aluminum disks with different roughness were investigated in the range $4000-530 \mathrm{~cm}^{-1}$ (Figure $1 \mathrm{~A}$ ). To improve readability, FTIR spectra are highlighted in the range $4000-1200 \mathrm{~cm}^{-1}$ (Figure 1B). In Figure 1, the major infrared absorption features at 3700-3100, 1558 and $1463 \mathrm{~cm}^{-1}$ are assigned to AlO-H stretching modes on the outer geometrical surface of the $\mathrm{Al}_{2} \mathrm{O}_{3}$ [52], and to oxalate skeleton vibrations ( $\mathrm{C}-\mathrm{O}$ stretching and $\mathrm{C}-\mathrm{H}$ bending) as a residue of the applied precursor, respectively [53].

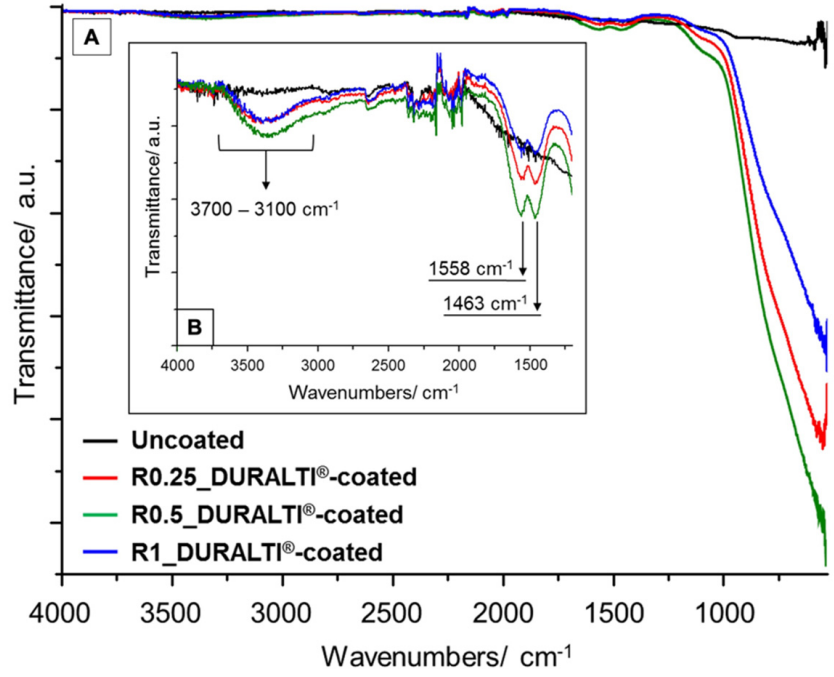

Figure 1. FTIR spectra of R0.25, R0.5 and R1 uncoated and DURALTI ${ }^{\circledR}$-coated aluminum disks in the range between (A) 4000-530 $\mathrm{cm}^{-1}$ and $4000-1200 \mathrm{~cm}^{-1}$ (B). 
Compared to the uncoated sample, the infrared spectra of coated aluminum disks show a strong and very broad band above $1180 \mathrm{~cm}^{-1}$ (Figure 1A), which is attributed to (i) asymmetric and symmetric bending modes of $\mathrm{Al}-\mathrm{O}-\mathrm{Al}$ bonds [54,55]; (ii) stretching vibrations of $\mathrm{Al}-\mathrm{O}$ bonds [56] and(iii) $\mathrm{Ti}-\mathrm{O}-\mathrm{Ti}, \mathrm{Al}-\mathrm{O}-\mathrm{Al}$ and hetero metal-oxygen Ti-O-Al bonds $[54,57]$.

\subsection{Time-Course Assay}

Counts $(\mathrm{CFU} / \mathrm{mL})$ of Gram-positive bacteria, at different exposure times on uncoated aluminum disks with 3 different types of roughness, subjected to UV and alcohol sanitizing methods, are reported in Figure 2.
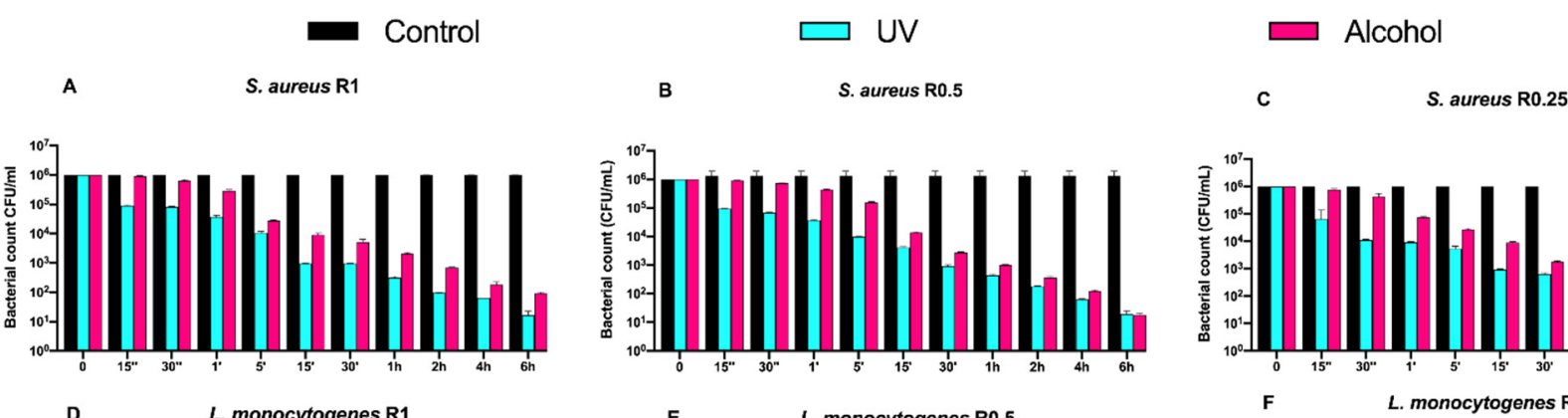

E

L. monocytogenes R0.5
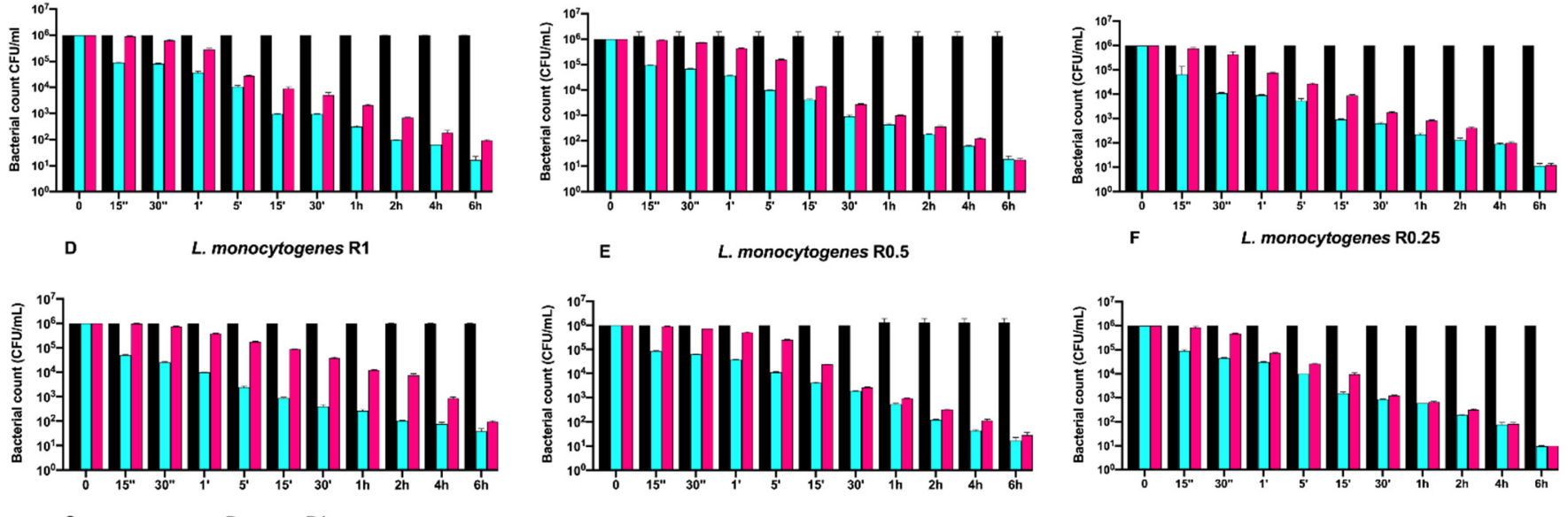

H

B. cereus R0.5

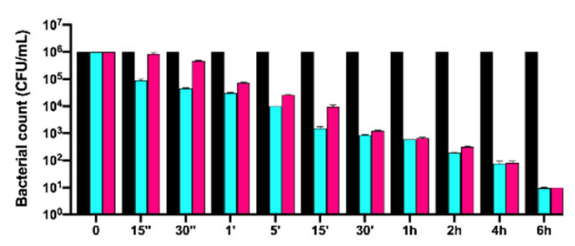

I

B.cereus R0.25
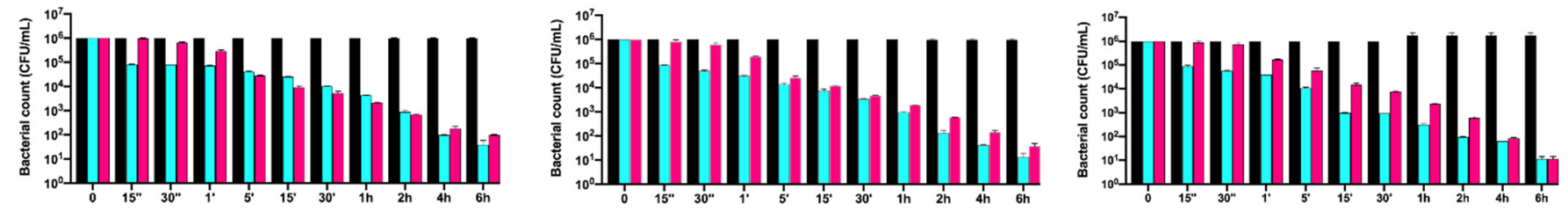

$J$

E. faecalis $\mathbf{R 1}$

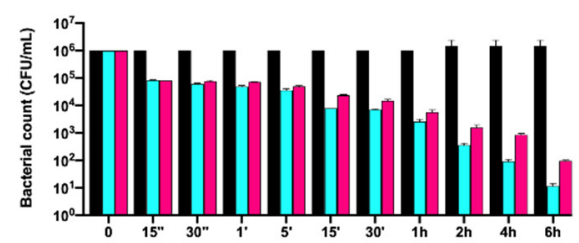

K

E. faecalis $\mathrm{R} 0.5$

E. faecalis $\mathrm{R} 0.25$
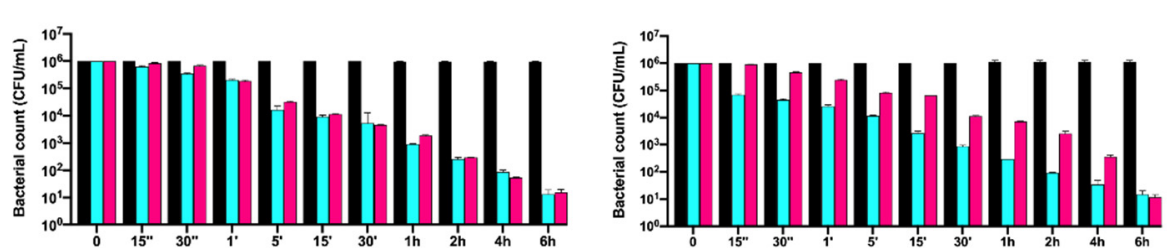

Figure 2. Graphical representation of Gram-positive bacterial counts (A-L) at different exposure times on uncoated aluminum disks with different surface roughness (R0.25, R0.5 and R1 $\mu \mathrm{m}$ ) and subjected to UV and alcohol sanitizing methods.

Regardless of the roughness and exposure time, no visible microbial count decrease was observed for all control disks. Both alcohol and UV treatments induced a timedependent microbial count decrease down to 5 logarithms (from $10^{6}$ to $10^{1} \mathrm{CFU} / \mathrm{mL}$ ) after $6 \mathrm{~h}$ of exposure, with a slower trend for the former (Figure 2A-L).

Then, we also evaluated the time-course counts of the same Gram-positive bacteria on DURALTI ${ }^{\circledR}$-coated disks (Figure 3 ). 

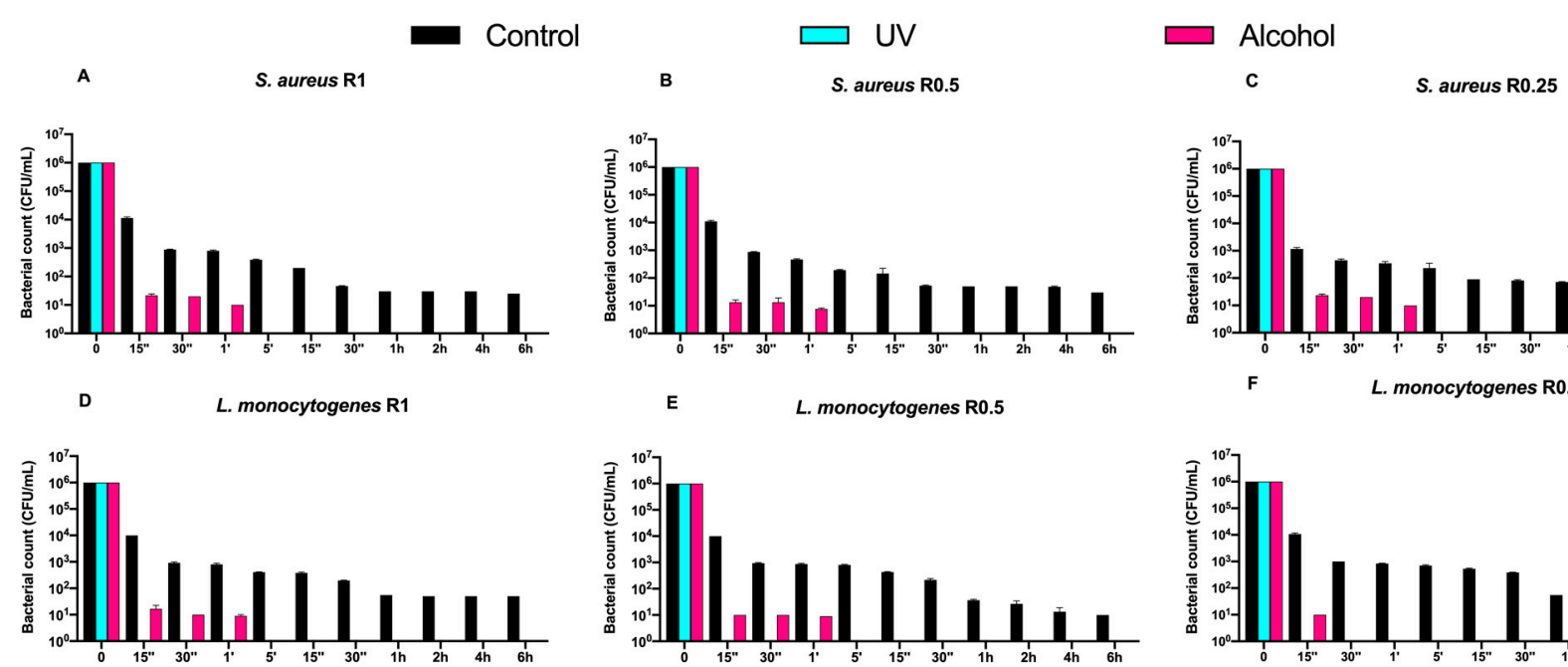

E

L. monocytogenes R0.5

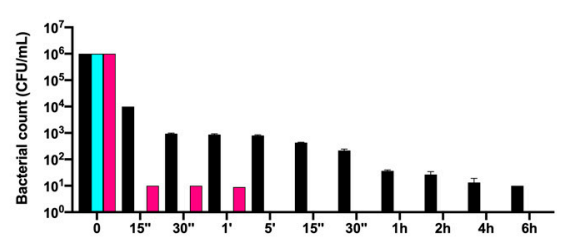

H

B. cereus R0.5
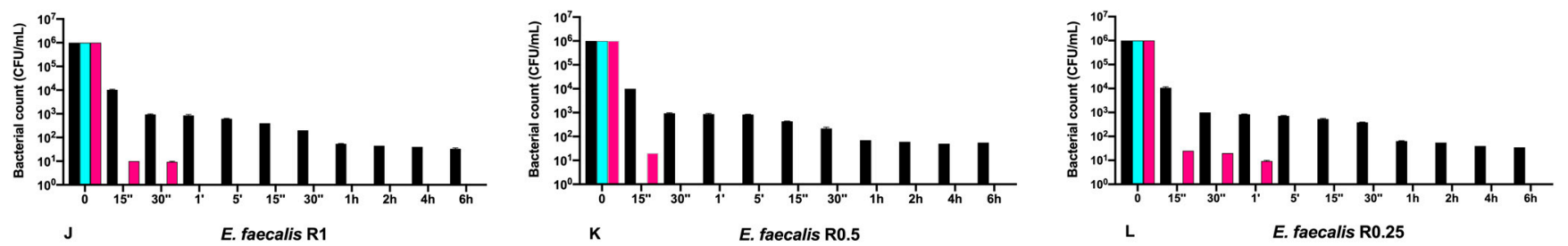

E. faecalis R1

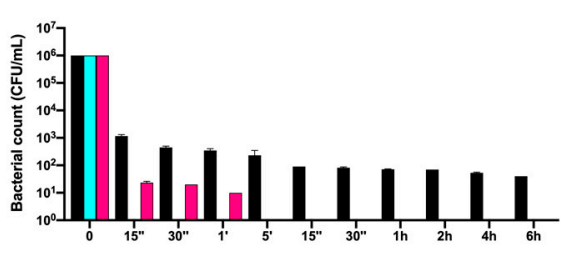

$\mathbf{F}$

L. monocytogenes $\mathrm{R} 0.25$

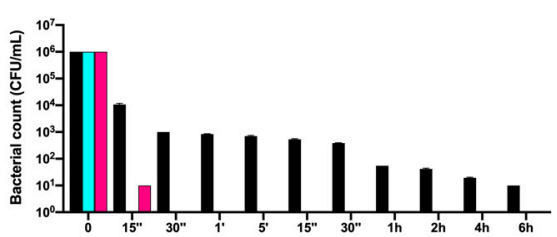

I

B. cereus $\mathrm{R} 0.25$

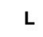

E. faecalis R0.25
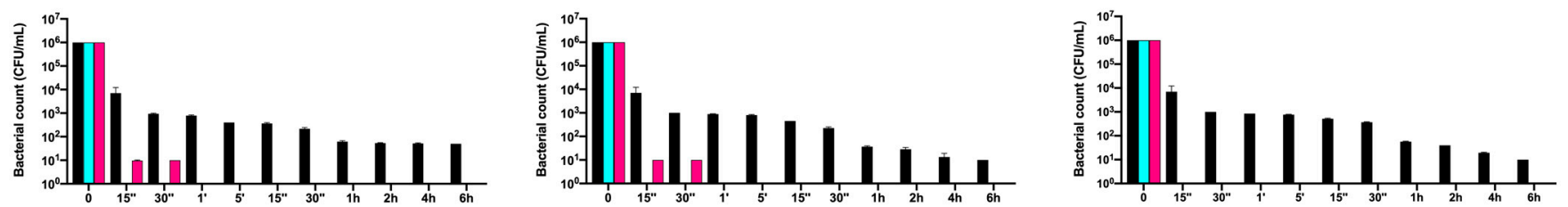

Figure 3. Graphical representation of Gram-positive bacterial (A-L) counts at different exposure times on DURALTI ${ }^{\circledR}$-coated aluminum disks with different surface roughness (R0.25, R0.5 and R1 $\mu \mathrm{m}$ ) and subjected to UV and alcohol sanitizing methods.

Dealing with the controls, a 4-logarithmic decrease (from $10^{6}$ to $10^{2} \mathrm{CFU} / \mathrm{mL}$ ) was observed on the coated disks after $6 \mathrm{~h}$, regardless of roughness. Moreover, an overall bacterial growth inhibition was already observed for all strains before $15^{\prime \prime}$ of UV exposure regardless of roughness, while a slightly slower trend was observed for strains subjected to alcohol sanitization.

For instance, Staphylococcus aureus ATCC 6538 was already inhibited after 1' of alcohol exposure regardless of roughness (Figure 3A-C), while Listeria monocytogenes NCTT 10888 was inhibited after $1^{\prime}$ only at R1 and R0.5, and after $15^{\prime \prime}$ at R0.25 (Figure 3D,E). Further, Bacillus cereus ATCC 14579 was inhibited at different times of alcohol exposure depending on roughness, in particular after $30^{\prime \prime}$ and $15^{\prime \prime}$ and $1^{\prime}$ at R1, R0.5, and R0.25, respectively (Figure 3G-I). Conversely, Enterococcus faecalis ATCC 29212 was equally inhibited after 30" of alcohol exposure at R1 and R0.5, and after $15^{\prime \prime}$ at R0.05 (Figure 3J-L).

Subsequently, we evaluated the growth trend of Gram-negative bacteria on both uncoated and DURALTI ${ }^{\circledR}$-coated disks (Figures 4 and 5).

As observed for Gram-positive bacteria, the uncoated surface did not decrease the Gram-negative load regardless of roughness and strain (Figure 4A-L). In a manner different to Gram-positive bacteria, UV treatment was already able to completely inhibit Salmonella Typhimurium ATCC 1402, Yersinia enterocolitica ATCC 9610 and Pseudomonas aeruginosa ATCC 27588 before $15^{\prime \prime}$, only at R1 (Figure 3A,D,G).

Conversely, alcohol treatment resulted in an overall 4-logarithmic bacterial growth reduction (from $10^{6}$ to $10^{2} \mathrm{CFU} / \mathrm{mL}$ ) after $6 \mathrm{~h}$, with the only exception of Pseudomonas 
aeruginosa ATCC 27,588 at $\mathrm{R} 1$ and R0.5, where such a reduction was achieved after $2 \mathrm{~h}$ and $1 \mathrm{~h}$, respectively (Figure $4 \mathrm{G}, \mathrm{H}$ ).

- Control

$\square$ UV

E.coli R0.5

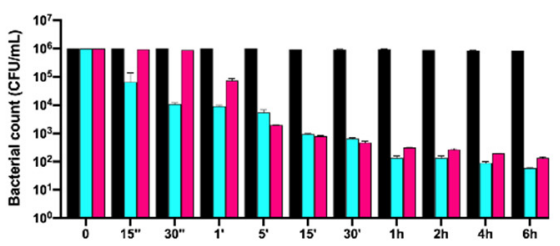

E

S. Typhimurium R0.5

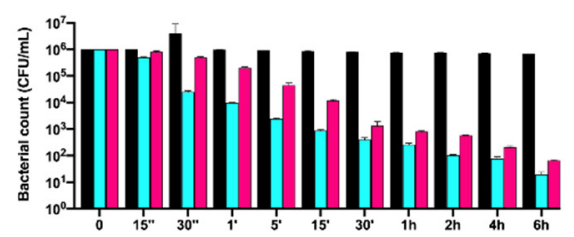

H P. aeruginosa R0.5
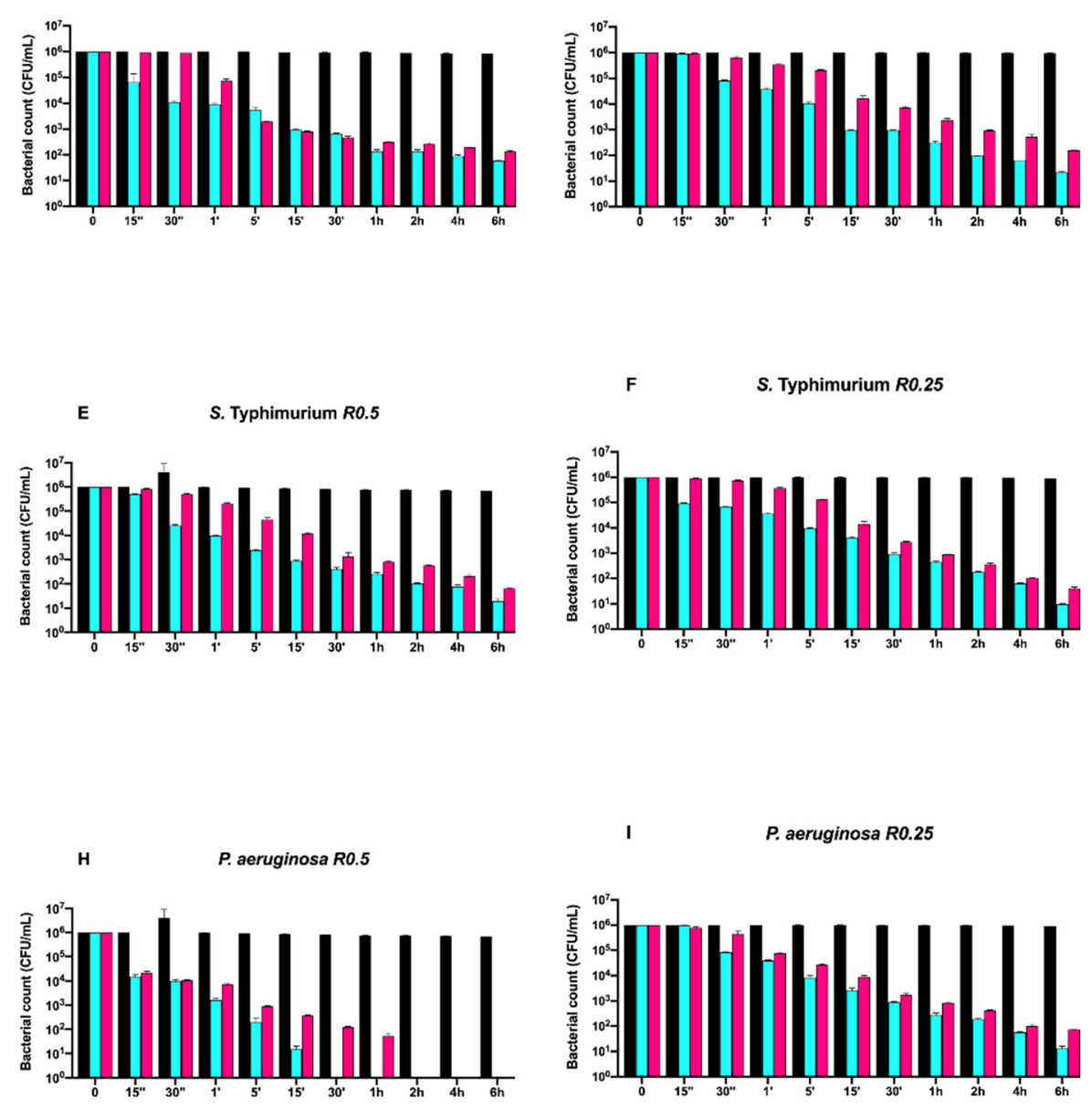

F

S. Typhimurium $R 0.25$
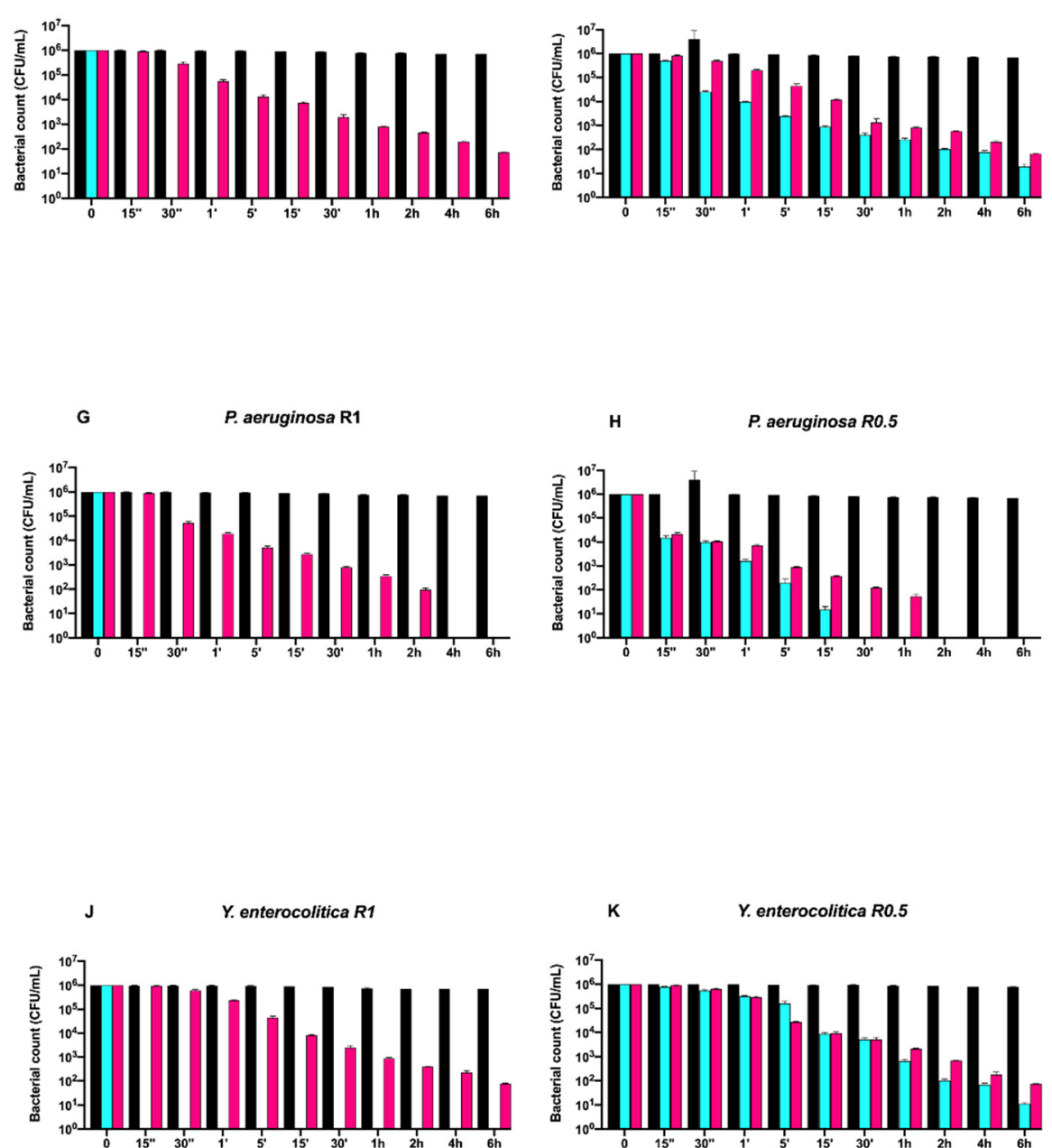

Figure 4. Graphical representation of Gram-negative bacterial counts (A-L) at different exposure times on uncoated aluminum disks with different surface roughness (R0.25, R0.5 and R1 $\mu \mathrm{m})$ and subjected to UV and alcohol sanitizing methods. 


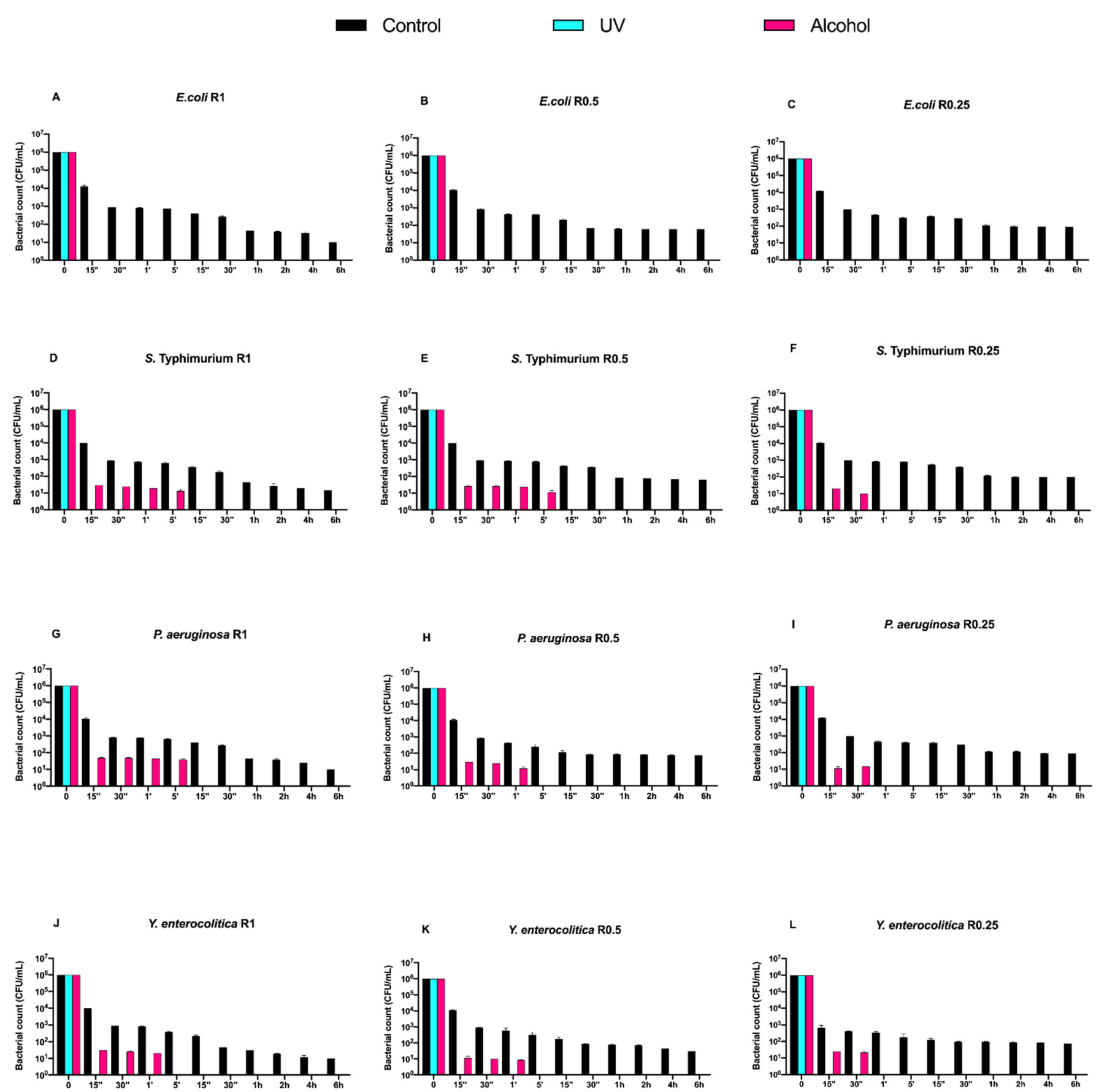

Figure 5. Graphical representation of Gram-negative bacterial counts (A-L) at different exposure times on DURALTI ${ }^{\circledR}$-coated aluminum disks with different surface roughness (R0.25, R0.5 and R1 $\left.\mu \mathrm{m}\right)$ and subjected to UV and alcohol sanitizing methods.

Then, we evaluated the effect of the DURALTI ${ }^{\circledR}$ coating on the same strains, roughness and treatments (Figure 5).

An overall microbial growth reduction (from $10^{6}$ to $10^{2} \mathrm{CFU} / \mathrm{mL}$ ) after a $6 \mathrm{~h}$ exposure was observed in control samples, with the only exception of all strains at R1, for which a $10^{1} \mathrm{CFU} / \mathrm{mL}$ concentration was achieved (Figure 5A-L). Moreover, UV treatment resulted in a complete microbial count decrease in all strains already before $15^{\prime \prime}$, as observed for Gram-positive bacteria.

Different trends were observed after the alcohol treatment. Dealing with Escherichia coli ATCC 25922, a complete inhibition was already achieved before $15^{\prime \prime}$, regardless of 
roughness (Figure 5A-C). On the other hand, Salmonella Typhimurium ATCC 1402 was completely inhibited after a $5^{\prime}$ at R1 and R0.5, and after a 30" at R0.25 (Figure 5D-F). A $5^{\prime}$ exposure was also sufficient to completely inhibit Pseudomonas aeruginosa ATCC 27588 at R1, while such a result was achieved after $1^{\prime}$ and $30^{\prime \prime}$ at R0.5 and R0.25, respectively (Figure 5G-I). Yersinia enterocolitica ATCC 9610 was inhibited after $1^{\prime}$ at R1 and R0.5, and after $30^{\prime \prime}$ at R0.25 (Figure 5J-L).

\subsection{Environmental Scanning Microscopy Analysis (ESEM)}

ESEM micrographs of both uncoated and DURALTI ${ }^{\circledR}$-coated aluminum disks are reported in Figure 6.
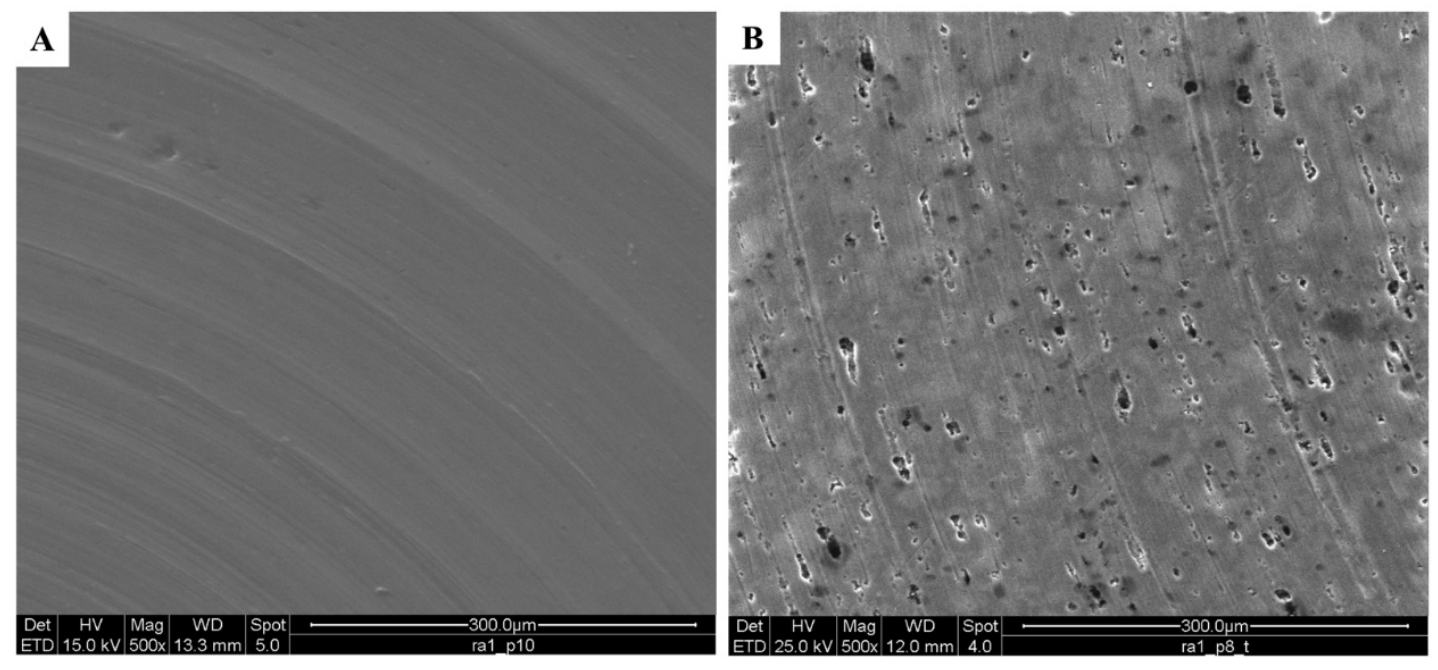

C

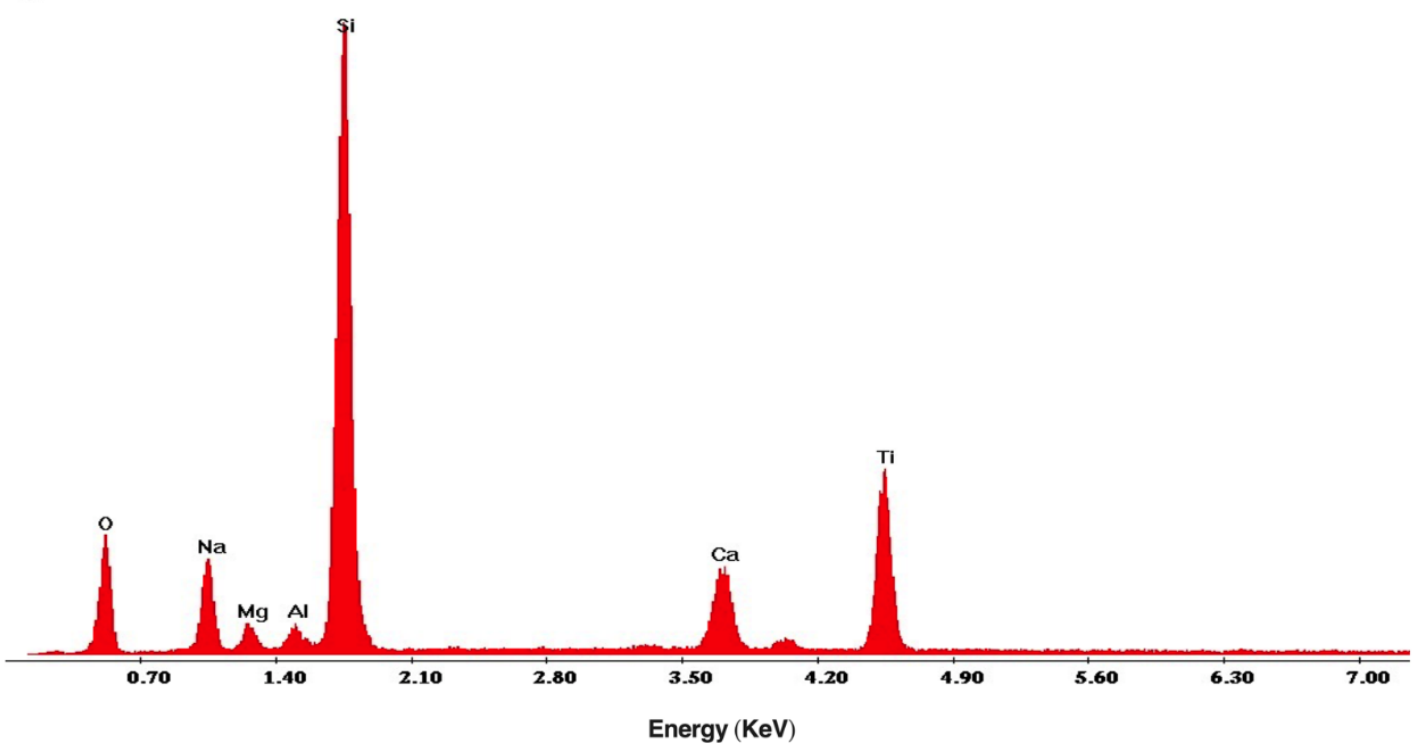

Figure 6. ESEM morphological analysis of (A) uncoated, (B) DURALTI ${ }^{\circledR}$-coated aluminum disks at 1 $\mu \mathrm{m}$ roughness; (C) X-EDS microanalysis of a DURALTI ${ }^{\circledR}$-coated aluminum disk at $1 \mu \mathrm{m}$ roughness.

The micrograph of the uncoated aluminum disk clearly shows typical signs of the turning process (Figure 6A), with the characteristic parallel grooves resulting from the gradual removal of surface layers. Instead, the micrograph of DURALTI ${ }^{\circledR}$-coated aluminum disk reveals a heterogeneous structure with the presence of clusters and pores (Figure 6B). Moreover, the X-EDS spectrum of the DURALTI ${ }^{\circledR}$-coated aluminum disk confirmed the presence of $\mathrm{TiO}_{2}$ (Figure $6 \mathrm{C}$ ). 


\subsection{CA and Wettability}

The surface wettability of the DURALTI ${ }^{\circledR}$-coated aluminum samples with the 3 different roughness, was investigated by steady-state water CA measurements. Images and CA values of both uncoated and coated aluminum disks are shown in Figure 7 and listed in Table 1 , respectively.
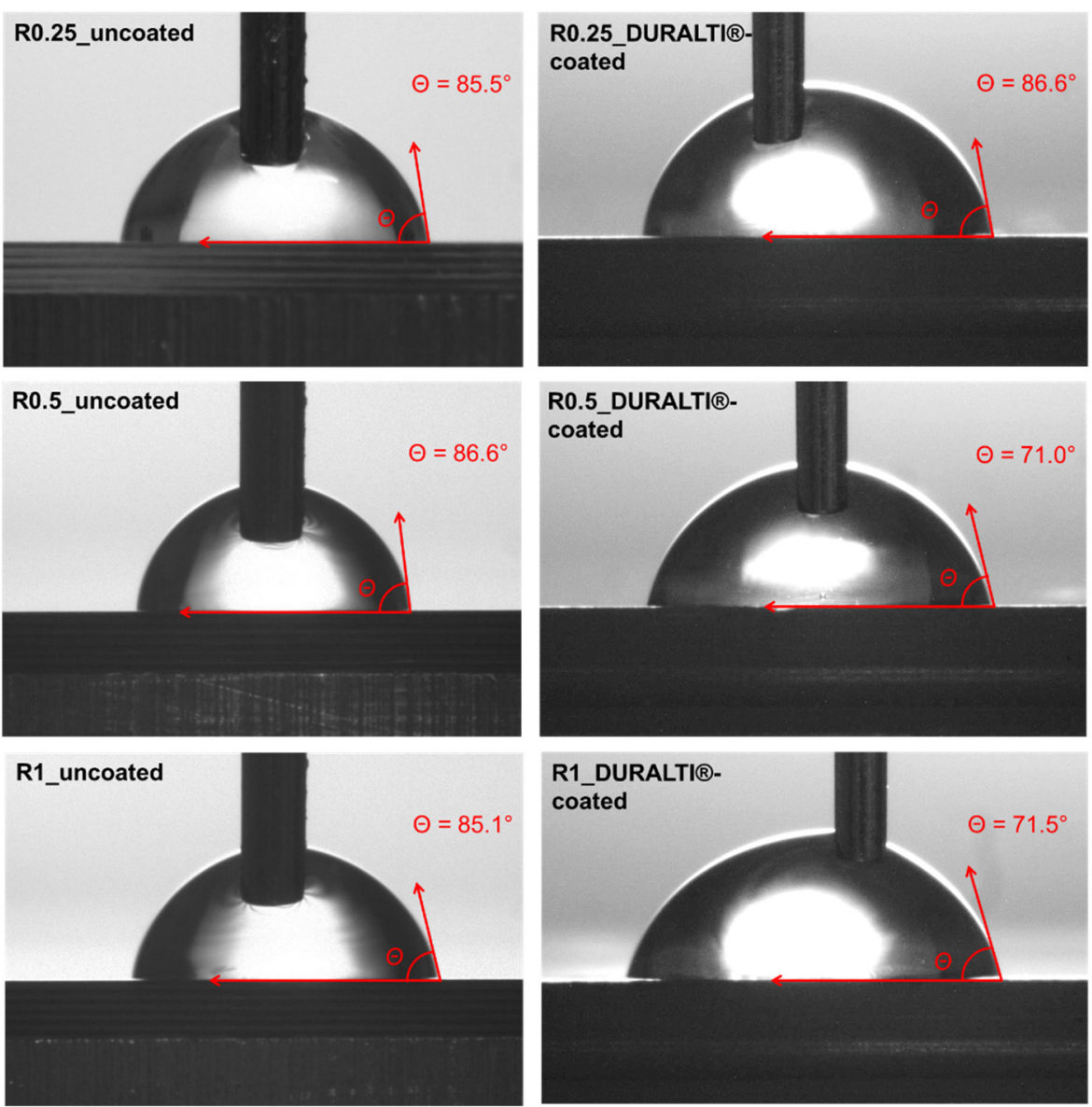

Figure 7. Images of steady-state water CA of uncoated and DURALTI ${ }^{\circledR}$-coated aluminum disks.

Table 1. Roughness profile and CA measurements of uncoated and coated aluminum disks. The standard deviation was computed considering ten repeated tests performed on each sample.

\begin{tabular}{cccc}
\hline Sample & Roughness $(\mu \mathrm{m})$ & CA $\left(^{\circ}\right)$ & CA Change $(\%)$ \\
\hline R0.25 uncoated & 0.25 & $85.4 \pm 4.2^{\circ}$ & \multirow{2}{*}{1.3} \\
R0.25 DURALTI $^{\circledR}$-coated & 0.25 & $86.7 \pm 1.5^{\circ}$ & \\
\hline R0.5 uncoated & 0.50 & $86.7 \pm 2.1^{\circ}$ & \multirow{2}{*}{-18.0} \\
R0.5 DURALTI ${ }^{\circledR}$-coated & 0.50 & $71.1 \pm 6.0^{\circ}$ & \\
\hline R1 uncoated & 1.00 & $85.0 \pm 1.3^{\circ}$ & \multirow{2}{*}{-16.0} \\
R1 DURALTI $^{\circledR}$-coated & 1.00 & $71.4 \pm 5.4^{\circ}$ & \\
\hline
\end{tabular}

The CA percentage change between uncoated and coated samples (Equation (1)) was calculated for each sample as an index of roughness influence on coating wettability: the greater the difference in the negative percentage change in the $\mathrm{CA}$, the more hydrophilic the surface.

As shown in Figure 7 and Table 1, the surface roughness of uncoated samples does not significantly affect the CA values that remain almost constant at around $85-86^{\circ}$. Similar behavior was observed for coated samples at R0.25, where the water drop placed on the 
surface led to a negligible hydrophilicity effect. Conversely, the surface wettability of the coated samples slightly increases at R0.5 and R1. Indeed, the analysis of the CA change showed that the greatest differences were observed at R0.5 (-18.0\%) and R1 (-16.0\%), while the smallest difference was observed at R0.25 (1.3\%).

\section{Discussion}

\subsection{Time-Course Assay}

Nowadays, aluminum is a ubiquitous material present in many foodstuffs that, in turn, become its main exposure source for humans. Despite the daily intake of 1.7 to $13 \mathrm{mg}$ of aluminum that has been set by EFSA for a $60 \mathrm{~kg}$ adult, the untoward release from food contact materials, such as aluminum foils, trays, cans, cookware, utensils and food packaging, cannot be neglected [6,7]. It is therefore fundamental to find reliable solutions to prevent such an untoward release and, at the same time, exert a rapid bacteriostatic and/or bactericidal effect. In this regard, nanotechnological coatings have shown great potential in terms of biocompatibility and leaching prevention [19-21,35].

The aim of this study was to provide more details concerning the time required by an FCM-certified coating (DURALTI ${ }^{\circledR}$ ) deposited on aluminum disks with different roughness, to exert its bacteriostatic/bactericidal effect against different Gram-negative and Gram-positive bacterial strains.

In fact, in a previous study, we observed that, after $12 \mathrm{~h}$ of exposure of the same bacteria, a partial bactericidal effect (from $10^{6}$ to $10^{2} \mathrm{CFU} / \mathrm{mL}$ ) occurred on DURALTI ${ }^{\circledR}$. coated surfaces without any sanitizing treatment (UVC and alcohol) and regardless of roughness, while a complete inhibition of bacterial growth occurred when each of the sanitizing treatments was applied [21].

We, therefore, carried out a time-course $(0-6 \mathrm{~h})$ evaluation to possibly observe the aforementioned effects before $12 \mathrm{~h}$, and to better frame the time required to achieve the most effective inhibition.

Interestingly, DURALTI ${ }^{\circledR}$-coated aluminum disks decreased both Gram-positive and Gram-negative bacterial loads from $10^{6}$ to $10^{2} \mathrm{CFU} / \mathrm{mL}$ already after $6 \mathrm{~h}$, regardless of roughness. On the other hand, both Gram-positive and Gram-negative results were completely inhibited in a time ranging from $15^{\prime \prime}$ to $1^{\prime}$, once each sanitizing treatment was applied.

As for the uncoated disks, a different trend was observed for Gram-positive and Gram-negative bacteria. A bacteriostatic trend was observed for the controls, regardless of roughness and treatment, and a bactericidal one when treatments were applied, never reaching a complete removal of the bacteria within $6 \mathrm{~h}$. This observation was in agreement with our previous work, in which such a trend was kept up to $12 \mathrm{~h}$ [21], thus confirming the hypothesis of a strong binding possibly occurring at the bacteria/surface interface. Although many mechanisms have been proposed to explain such binding (thermodynamic theory, Lifshitz-van der Waals, and electrostatic-double layer interactions, ionic strength and $\mathrm{pH}$ ) $[20,21,58]$, several studies also demonstrated a direct correlation between bacterial adhesion and surface roughness increase above $0.2 \mu \mathrm{m}$ [59-62]. Moreover, despite the trend of controls and treatments of Gram-negative bacteria resulting in more or less the same Gram-positive strains, it is worth noting that a complete removal of the bacteria occurred after $15^{\prime \prime}$ and $15^{\prime}$ of UVC exposure at R1 for all strains and at R0.5 for Pseudomonas aeruginosa ATCC 27588, respectively. Interestingly, Pseudomonas aeruginosa ATCC 27588 was also completely inhibited by alcohol after $1 \mathrm{~h}$ at R1, and after $2 \mathrm{~h}$ at R0.5. Even in this case, the synergistic effect of UVC treatment and surface roughness was in agreement with our previous study, in which a complete bacterial growth inhibition after $12 \mathrm{~h}$ of exposure with UVC at R1 was observed [21]. In this sense, some studies evidenced how bacterial adhesion and biofilm formation in some cases can also be negatively influenced by higher surface roughness, in particular for Pseudomonas aeruginosa [63,64], despite the fact that they are often positively correlated with such higher roughness. 


\subsection{FTIR Characterization}

FTIR characterization, CA measurements and ESEM analysis confirmed the successful deposition of the $\mathrm{Al}_{2} \mathrm{O}_{3}-\mathrm{TiO}_{2}$ thin film on DURALTI ${ }^{\circledR}$-coated disks.

In particular, ATR-FTIR spectroscopy is a powerful tool for investigating the functional groups present on the surface of treated materials, due to its sensitivity and penetration depth of only a few micrometers.

Since crystallinity degree, as well as morphology and particle size, can affect the IR bands' position and intensity, such peaks can be correlated with the phase evolution in titania-alumina composites [54]. Therefore, the prominent composition features of the coating can be characterized by absorption bands assigned to vibrations of functional groups typical of the applied coating. Indeed, compared to the reference aluminum sample, the infrared spectra of DURALTI ${ }^{\circledR}$-coated disks revealed characteristic absorption peaks assigned to bending modes of $\mathrm{Al}-\mathrm{O}-\mathrm{Al}$ bonds [54,55], and to stretching vibrations of $\mathrm{AlO}-$ $\mathrm{H}$ [52], $\mathrm{Al}-\mathrm{O}$ [56], Ti-O-Ti, $\mathrm{Al}-\mathrm{O}-\mathrm{Al}$ and $-\mathrm{Ti}-\mathrm{O}-\mathrm{Al}-$ bonds [54,57], confirming the total coverage of pristine aluminum surfaces by $\mathrm{Al}_{2} \mathrm{O}_{3}-\mathrm{TiO}_{2}$ coating. Furthermore, the deposition of $\mathrm{Al}_{2} \mathrm{O}_{3}-\mathrm{TiO}_{2}$ coating led to changes in aluminum disk wettability, as demonstrated by the $\mathrm{CA}$ values. As reported in literature [65], the chemical composition, surface morphology and roughness affect the CA value, according to the Wenzel model [66]. Thus, a lowering in the CA reflects an increase in the surface tension and, consequently, an improvement in the surface hydrophilicity.

In this study, $\mathrm{CA}$ measurements of $\mathrm{Al}_{2} \mathrm{O}_{3}-\mathrm{TiO}_{2}$-coated aluminum disks demonstrated enhanced hydrophilicity compared to uncoated samples, caused by the presence of polar chemical groups, which increased the surface energy of coated samples. In particular, experimental findings suggested that surface roughness values over $0.5 \mu \mathrm{m}$ equally affect the $\mathrm{Al}_{2} \mathrm{O}_{3}-\mathrm{TiO}_{2}$ coating morphologies, thus further influencing the static CA. Indeed, above such roughness, the porosity of the applied coating does not improve water droplet absorption. This behavior demonstrates the enhancement of the hydrophilic properties of $\mathrm{Al}_{2} \mathrm{O}_{3}-\mathrm{TiO}_{2}$ coating applied on aluminum disks in agreement with the performance reported for a similar coating $[67,68]$.

\subsection{ESEM Analysis}

ESEM micrographs carried out on DURALTI ${ }^{\circledR}$-coated surfaces show the presence of a heterogeneous structure, reasonably related to the presence of porous anodized coating.

As proposed by Thukkaram et al. [69], such heterogeneity in the surface morphology can trigger the release of $\mathrm{TiO}_{2}$ nanoparticles and the resulting activation of their intrinsic antibacterial properties. Such properties occur as a consequence of further exposure to $\mathrm{UVC}$, promoting free radical release and leading to the killing of pathogenic bacteria [35].

The capability of tuning $\mathrm{Al}_{2} \mathrm{O}_{3}$ porosity and shaping has been thoroughly investigated over the last decades, paving the way to its use in a wide range of fields, including FCM.

\section{Conclusions}

The DURALTI ${ }^{\circledR}$ coating confirmed its ability to induce a 4-logarithmic decrease (from $10^{6}$ to $10^{2} \mathrm{CFU} / \mathrm{mL}$ ) against both Gram-negative and Gram-positive bacteria regardless of roughness, but we demonstrated that a $12 \mathrm{~h}$ exposure is overestimated since such a decrease already occurs after $6 \mathrm{~h}$.

Moreover, we highlighted that all bacteria were completely inhibited in a time ranging from $15^{\prime \prime}$ to $1^{\prime}$, after the application of each sanitizing treatment.

Despite some study limitations, such as the lack of a biofilm assay on uncoated and DURALTI ${ }^{\circledR}$-coated surfaces, we believe that the results are innovative since this is one of the first reports dealing with a coating approved for contact with food, and endowed with a self-antibacterial activity. This is important in light of the growing awareness of the potential of nanotechnologically-treated FCM as a new frontier in the prevention of microbial adhesion and growth in the food industry, as well as in the reduction of the abuse of corrosive and toxic sanitizing agents. 
Author Contributions: Conceptualization, A.D.C.; methodology, C.S., R.I., A.M. and V.T.; validation, A.D.C., C.S. and R.C.; formal analysis, A.D.C., A.M. and S.R.; writing-original draft preparation, A.D.C., G.R., A.M. and V.T.; writing-review and editing, A.D.C., G.R. and S.G.; visualization, C.S., G.R. and V.T.; supervision, S.R., G.R., A.R.L. and R.S.; project administration, A.D.C. and C.S.; funding acquisition, A.D.C. All authors have read and agreed to the published version of the manuscript.

Funding: This research received no external funding.

Institutional Review Board Statement: Not applicable.

Informed Consent Statement: Not applicable.

Data Availability Statement: The data presented in this study are available on request from the corresponding authors.

Conflicts of Interest: The authors declare no conflict of interest.

\section{References}

1. Stahl, T.; Falk, S.; Rohrbeck, A.; Georgii, S.; Herzog, C.; Wiegand, A.; Hotz, S.; Boschek, B.; Zorn, H.; Brunn, H. Migration of aluminum from food contact materials to food-a health risk for consumers? Part I of III: Exposure to aluminum, release of aluminum, tolerable weekly intake (TWI), toxicological effects of aluminum, study design, and methods. Environ. Sci. Eur. 2017, 29, 19. [CrossRef]

2. Danielsson, R.; Eriksson, H. Aluminium adjuvants in vaccines-A way to modulate the immune response. Semin. Cell Dev. Biol. 2021, 115, 3-9. [CrossRef]

3. Bratakos, S.M.; Lazou, A.E.; Bratakos, M.S.; Lazos, E.S. Aluminium in food and daily dietary intake estimate in Greece. Food Addit. Contam. Part B 2012, 5, 33-44. [CrossRef]

4. Pennington, J.A.T. Aluminium content of foods and diets. Food Addit. Contam. 1988, 5, 161-232. [CrossRef]

5. Sato, K.; Suzuki, I.; Kubota, H.; Furusho, N.; Inoue, T.; Yasukouchi, Y.; Akiyama, H. Estimation of daily aluminum intake in Japan based on food consumption inspection results: Impact of food additives. Food Sci. Nutr. 2014, 2, 389-397. [CrossRef]

6. Aguilar, F.; Autrup, H.; Barlow, S.; Castle, L.; Crebelli, R.; Dekant, W.; Gontard, N.; Gott, D.; Grilli, S.; Leclercq, C.; et al. Safety of aluminium from dietary intake-Scientific Opinion of the Panel on Food Additives, Flavourings, Processing Aids and Food Contact Materials (AFC). EFSA J. 2008, 754, 1-34. [CrossRef]

7. Sander, S.; Kappenstein, O.; Ebner, I.; Fritsch, K.-A.; Schmidt, R.; Pfaff, K.; Luch, A. Release of aluminium and thallium ions from uncoated food contact materials made of aluminium alloys into food and food simulant. PLoS ONE 2018, 13, e0200778. [CrossRef]

8. Guildford, A.; Poletti, T.; Osbourne, L.; Di Cerbo, A.; Gatti, A.; Santin, M. Nanoparticles of a different source induce different patterns of activation in key biochemical and cellular components of the host response. J. R. Soc. Interface 2009, 6, $1213-1221$. [CrossRef]

9. Di Cerbo, A.; Canello, S.; Guidetti, G.; Fiore, F.; Corsi, L.; Rubattu, N.; Testa, C.; Cocco, R. Adverse food reactions in dogs due to antibiotic residues in pet food: A preliminary study. Vet. Ital. 2018, 54, 137-146. [CrossRef]

10. European Parliament and Council of European Union. Regulation (EC) No 1333/2008 on Food Additives. 2008. Available online: https:/ / eur-lex.europa.eu/legal-content/EN/TXT/HTML/?uri=CELEX:32008R1333\&from=en (accessed on 4 October 2021).

11. Council of Europe. Resolution CM/Res(2013)9 on Metals and Alloys Used in Food Contact Materials and Articles. 2013. Available online: https:/ / search.coe.int/cm/Pages/result_details.aspx?ObjectID=09000016805c8094 (accessed on 4 October 2021).

12. Igbokwe, I.O.; Igwenagu, E.; Igbokwe, N.A. Aluminium toxicosis: A review of toxic actions and effects. Interdiscip. Toxicol. 2019, 12, 45-70. [CrossRef]

13. Yu, H.; Zhang, J.; Ji, Q.; Yu, K.; Wang, P.; Song, M.; Cao, Z.; Zhang, X.; Li, Y. Melatonin alleviates aluminium chloride-induced immunotoxicity by inhibiting oxidative stress and apoptosis associated with the activation of Nrf2 signaling pathway. Ecotoxicol. Environ. Saf. 2019, 173, 131-141. [CrossRef]

14. El Hangouche, A.J.; Fennich, H.; Alaika, O.; Dakka, T.; Raissouni, Z.; Oukerraj, L.; Doghmi, N.; Cherti, M. Reversible Myocardial Injury and Intraventricular Thrombus Associated with Aluminium Phosphide Poisoning. Case Rep. Cardiol. 2017, $2017,6287015$. [CrossRef]

15. Mujika, J.I.; Dalla Torre, G.; Formoso, E.; Grande-Aztatzi, R.; Grabowski, S.J.; Exley, C.; Lopez, X. Aluminum's preferential binding site in proteins: Sidechain of amino acids versus backbone interactions. J. Inorg. Biochem. 2018, 181, 111-116. [CrossRef] [PubMed]

16. Wei, X.; Wei, H.; Yang, D.; Li, D.; Yang, X.; He, M.; Lin, E.; Wu, B. Effect of Aluminum Exposure on Glucose Metabolism and Its Mechanism in Rats. Biol. Trace Elem. Res. 2018, 186, 450-456. [CrossRef]

17. European Parliament and Council of European Union. Regulation (EC) No 1935/2004 on Materials and Articles Intended to Come into Contact with Food. 2004. Available online: https:/ / eur-lex.europa.eu/legal-content/EN/TXT/HTML/?uri=CELEX: 32004R1935\&from=IT (accessed on 4 October 2021).

18. Alfei, S.; Marengo, B.; Zuccari, G. Nanotechnology application in food packaging: A plethora of opportunities versus pending risks assessment and public concerns. Food Res. Int. 2020, 137, 109664. [CrossRef] 
19. Di Cerbo, A.; Rosace, G.; Rea, S.; Stocchi, R.; Morales-Medina, J.C.; Canton, R.; Mescola, A.; Condo, C.; Loschi, A.R.; Sabia, C. Time-Course Study of the Antibacterial Activity of an Amorphous SiOxCyHz Coating Certified for Food Contact. Antibiotics 2021, 10, 901. [CrossRef]

20. Di Cerbo, A.; Mescola, A.; Rosace, G.; Stocchi, R.; Rossi, G.; Alessandrini, A.; Preziuso, S.; Scarano, A.; Rea, S.; Loschi, A.R.; et al. Antibacterial Effect of Stainless Steel Surfaces Treated with a Nanotechnological Coating Approved for Food Contact. Microorganisms 2021, 9, 248. [CrossRef]

21. Di Cerbo, A.; Mescola, A.; Iseppi, R.; Canton, R.; Rossi, G.; Stocchi, R.; Loschi, A.R.; Alessandrini, A.; Rea, S.; Sabia, C. Antibacterial Effect of Aluminum Surfaces Untreated and Treated with a Special Anodizing Based on Titanium Oxide Approved for Food Contact. Biology 2020, 9, 456. [CrossRef]

22. Chaudhry, Q.; Scotter, M.; Blackburn, J.; Ross, B.; Boxall, A.; Castle, L.; Aitken, R.; Watkins, R. Applications and implications of nanotechnologies for the food sector. Food Addit. Contam. Part A 2008, 25, 241-258. [CrossRef]

23. Chaudhary, P.; Fatima, F.; Kumar, A. Relevance of Nanomaterials in Food Packaging and its Advanced Future Prospects. J. Inorg. Organomet. Polym. Mater. 2020, 30, 5180-5192. [CrossRef]

24. Lagarón, J.M. Multifunctional and Nanoreinforced Polymers for Food Packaging, 1st ed.; Elsevier Science: Amsterdam, The Netherlands, 2011; p. 736.

25. Pinto, R.J.B.; Daina, S.; Sadocco, P.; Neto, C.P.; Trindade, T. Antibacterial Activity of Nanocomposites of Copper and Cellulose. BioMed Res. Int. 2013, 2013, 280512. [CrossRef]

26. Mihindukulasuriya, S.; Lim, L.-T. Nanotechnology development in food packaging: A review. Trends Food Sci. Technol. 2014, 40, 149-167. [CrossRef]

27. Morris, M.A.; Padmanabhan, S.C.; Cruz-Romero, M.C.; Cummins, E.; Kerry, J.P. Development of active, nanoparticle, antimicrobial technologies for muscle-based packaging applications. Meat Sci 2017, 132, 163-178. [CrossRef]

28. Nile, S.H.; Baskar, V.; Selvaraj, D.; Nile, A.; Xiao, J.; Kai, G. Nanotechnologies in Food Science: Applications, Recent Trends, and Future Perspectives. Nano-Micro Lett. 2020, 12, 45. [CrossRef]

29. Yan, X.; He, B.; Liu, L.; Qu, G.; Shi, J.; Hu, L.; Jiang, G. Antibacterial mechanism of silver nanoparticles in Pseudomonas aeruginosa: Proteomics approach. Metallomics 2018, 10, 557-564. [CrossRef]

30. Dong, Z.-Y.; Rao, M.P.N.; Xiao, M.; Wang, H.-F.; Hozzein, W.N.; Chen, W.; Li, W.-J. Antibacterial Activity of Silver Nanoparticles against Staphylococcus warneri Synthesized Using Endophytic Bacteria by Photo-irradiation. Front. Microbiol. 2017, 8, 1090. [CrossRef]

31. Ramalingam, B.; Parandhaman, T.; Das, S.K. Antibacterial Effects of Biosynthesized Silver Nanoparticles on Surface Ultrastructure and Nanomechanical Properties of Gram-Negative Bacteria viz. Escherichia coli and Pseudomonas aeruginosa. ACS Appl. Mater. Interfaces 2016, 8, 4963-4976. [CrossRef]

32. Baptista, P.V.; McCusker, M.P.; Carvalho, A.; Ferreira, D.A.; Mohan, N.M.; Martins, M.; Fernandes, A.R. Nano-Strategies to Fight Multidrug Resistant Bacteria-“A Battle of the Titans". Front. Microbiol. 2018, 9, 1441. [CrossRef]

33. Natan, M.; Banin, E. From Nano to Micro: Using nanotechnology to combat microorganisms and their multidrug resistance. FEMS Microbiol. Rev. 2017, 41, 302-322. [CrossRef]

34. Shamaila, S.; Zafar, N.; Riaz, S.; Sharif, R.; Nazir, J.; Naseem, S. Gold Nanoparticles: An Efficient Antimicrobial Agent against Enteric Bacterial Human Pathogen. Nanomaterials 2016, 6, 71. [CrossRef]

35. Di Cerbo, A.; Pezzuto, F.; Scarano, A. Cytotoxic and Bacteriostatic Activity of Nanostructured TiO 2 Coatings. Pol. J. Microbiol. 2016, 65, 225-229. [CrossRef]

36. Garino, N.; Sanvitale, P.; Dumontel, B.; Laurenti, M.; Colilla, M.; Izquierdo-Barba, I.; Cauda, V.; Vallet-Regì, M. Zinc oxide nanocrystals as a nanoantibiotic and osteoinductive agent. RSC Adv. 2019, 9, 11312-11321. [CrossRef]

37. Wiacek, A.E. The wetting and interfacial properties of alumina surface treated with dipalmitoylphosphatidylcholine and lipase enzyme. Powder Technol. 2011, 212, 332-339. [CrossRef]

38. Wiącek, A.E.; Anitowska, E.; Delgado, A.V.; Hołysz, L.; Chibowski, E. The electrokinetic and rheological behavior of phosphatidylcholine-treated $\mathrm{TiO}_{2}$ suspensions. Colloids Surfaces A Physicochem. Eng. Asp. 2012, 440, 110-115. [CrossRef]

39. Jurak, M.; Wiacek, A.E.; Ładniak, A.; Przykaza, K.; Szafran, K. What affects the biocompatibility of polymers? Adv. Colloid Interface Sci. 2021, 294, 102451. [CrossRef]

40. Vallet-Regí, M.; González, B.; Izquierdo-Barba, I. Nanomaterials as Promising Alternative in the Infection Treatment. Int. J. Mol. Sci. 2019, 20, 3806. [CrossRef]

41. Xie, J.; Hung, Y.-C. Methodology to evaluate the antimicrobial effectiveness of UV-activated $\mathrm{TiO}_{2}$ nanoparticle-embedded cellulose acetate film. Food Control. 2019, 106, 106690. [CrossRef]

42. Pleskova, S.N.; Golubeva, I.S.; Verevkin, Y.K.; Pershin, E.A.; Burenina, V.N.; Korolichin, V.V. Photoinduced bactericidal activity of $\mathrm{TiO}_{2}$ films. Appl. Biochem. Microbiol. 2011, 47, 23-26. [CrossRef]

43. Khataee, R.; Heydari, V.; Moradkhannejhad, L.; Safarpour, M.; Joo, S.W. Self-Cleaning and Mechanical Properties of Modified White Cement with Nanostructured $\mathrm{TiO}_{2}$. J. Nanosci. Nanotechnol. 2013, 13, 5109-5114. [CrossRef]

44. de Dicastillo, C.L.; Guerrero Correa, M.; Martínez, F.B.; Streitt, C.; Galotto, M.J. Antimicrobial Effect of Titanium Dioxide Nanoparticles. In Antimicrobial Resistance; Mares, M., Erin Lim, S.H., Lai, K.-S., Cristina, R.-T., Eds.; IntechOpen: London, UK, 2019; p. 19. 
45. Gaser, G. Available online: https://www.gruppogaser.com/en/galvanic-treatments/anodizing/duralti--15 (accessed on 4 October 2021).

46. ASTM D4060. Standard Test Method for Abrasion Resistance of Organic Coatings by the Taber Abraser. Available online: https:/ / www.astm.org/Standards/D4060.htm (accessed on 4 October 2021).

47. ASTM B117. Standard Practice for Operating Salt Spray (Fog) Apparatus. Available online: https://www.astm.org/Standards / B117.htm (accessed on 4 October 2021).

48. DIN 10531. Food Hygiene-Production and Dispense of hot Beverages from Hot Beverage Appliances-Hygiene Requirements, Migration Test. 2011. Available online: https://infostore.saiglobal.com/en-us/Standards/DIN-10531-2011-432397_SAIG_DIN_ DIN_976731/ (accessed on 4 October 2021).

49. UNI 11460. Appliances for the Production and Dispense of Hot Beverages for Use in Commercial and Communities-Test Methods and Migration Limits of Lead and Nickel. 2012. Available online: http:/ / store.uni.com/catalogo/uni-11460-2012?__store=en\& from_store=it (accessed on 4 October 2021).

50. Gozdecka, A.; Wiaceek, A.E. Effect of UV radiation and chitosan coating on the adsorption-photocatalytic activity of $\mathrm{TiO}_{2}$ particles. Mater. Sci. Eng. C 2018, 93, 582-594. [CrossRef]

51. Wiacek, A.E.; Gozdecka, A.; Jurak, M. Physicochemical Characteristics of Chitosan-TiO ${ }_{2}$ Biomaterial. 1. Stability and Swelling Properties. Ind. Eng. Chem. Res. 2018, 57, 1859-1870. [CrossRef]

52. Cornelius, E.B.; Milliken, T.H.; Mills, G.A.; Oblad, A.G. Surface Strain in Oxide Cata1ysts-A1umina. J. Phys. Chem. 1955, 59, 809-813. [CrossRef]

53. Hug, S.J.; Bahnemann, D.B.D. Infrared spectra of oxalate, malonate and succinate adsorbed on the aqueous surface of rutile, anatase and lepidocrocite measured with in situ ATR-FTIR. J. Electron Spectrosc. Relat. Phenom. 2006, 150, 208-219. [CrossRef]

54. Ahmed, M.; Abdel-Messih, M. Structural and nano-composite features of TiO2-Al2O3 powders prepared by sol-gel method. J. Alloy. Compd. 2011, 509, 2154-2159. [CrossRef]

55. Urretavizcaya, G.; Cavalieri, A.L.; López, J.M.P.; Sobrados, I.; Sanz, J. Thermal Evolution of Alumina Prepared by the Sol-Gel Technique. J. Mater. Synth. Process. 1998, 6, 1-7. [CrossRef]

56. Adamczyk, A.; Długoń, E. The FTIR studies of gels and thin films of $\mathrm{Al}_{2} \mathrm{O}_{3}-\mathrm{TiO}_{2}$ and $\mathrm{Al}_{2} \mathrm{O}_{3}-\mathrm{TiO}_{2}-\mathrm{SiO}_{2}$ systems. Spectrochim. Acta Part A Mol. Biomol. Spectrosc. 2012, 89, 11-17. [CrossRef] [PubMed]

57. Tursiloadi, S.; Imai, H.; Hirashima, H. Preparation and characterization of mesoporous titania-alumina ceramic by modified sol-gel method. J. Non-Crystalline Solids 2004, 350, 271-276. [CrossRef]

58. Carniello, V.; Peterson, B.; van der Mei, H.C.; Busscher, H.J. Physico-chemistry from initial bacterial adhesion to surfaceprogrammed biofilm growth. Adv. Colloid Interface Sci. 2018, 261, 1-14. [CrossRef]

59. Yu, P.; Wang, C.; Zhou, J.; Jiang, L.; Xue, J.; Li, W. Influence of Surface Properties on Adhesion Forces and Attachment ofStreptococcus mutansto ZirconiaIn Vitro. BioMed Res. Int. 2016, 2016, 8901253. [CrossRef]

60. Yoda, I.; Koseki, H.; Tomita, M.; Shida, T.; Horiuchi, H.; Sakoda, H.; Osaki, M. Effect of surface roughness of biomaterials on Staphylococcus epidermidis adhesion. BMC Microbiol. 2014, 14, 234. [CrossRef] [PubMed]

61. Dantas, L.C.d.M.; Silva-Neto, J.P.d.; Dantas, T.S.; Naves, L.Z.; das Neves, F.D.; da Mota, A.S. Bacterial Adhesion and Surface Roughness for Different Clinical Techniques for Acrylic Polymethyl Methacrylate. Int. J. Dent. 2016, 2016, 8685796. [CrossRef]

62. Wu, S.; Zhang, B.; Liu, Y.; Suo, X.; Li, H. Influence of surface topography on bacterial adhesion: A review (Review). Biointerphases 2018, 13, 060801. [CrossRef]

63. Wu, S.; Altenried, S.; Zogg, A.; Zuber, F.; Maniura-Weber, K.; Ren, Q. Role of the Surface Nanoscale Roughness of Stainless Steel on Bacterial Adhesion and Microcolony Formation. ACS Omega 2018, 3, 6456-6464. [CrossRef] [PubMed]

64. Matalon, S.; Safadi, D.; Meirowitz, A.; Ormianer, Z. The Effect of Aging on the Roughness and Bacterial Adhesion of Lithium Disilicate and Zirconia Ceramics. J. Prosthodont. 2021, 30, 440-446. [CrossRef]

65. Chau, T.; Bruckard, W.; Koh, P.; Nguyen, A. A review of factors that affect contact angle and implications for flotation practice Adv. Colloid Interface Sci. 2009, 150, 106-115. [CrossRef] [PubMed]

66. Wang, X.; Zhang, Q. Insight into the Influence of Surface Roughness on the Wettability of Apatite and Dolomite. Minerals 2020, 10, 114. [CrossRef]

67. Zhang, Q.; Fan, Y.; $\mathrm{Xu}, \mathrm{N}$. Effect of the surface properties on filtration performance of $\mathrm{Al}_{2} \mathrm{O}_{3}-\mathrm{TiO}_{2}$ composite membrane. Sep Purif. Technol. 2009, 66, 306-312. [CrossRef]

68. Liu, Q.J.; Zhang, J.; Zhu, Z.; Jin, Y.; Wang, Q.H. Hydrophilic Properties of $\mathrm{TiO}_{2}-\mathrm{Al}_{2} \mathrm{O}_{3}$ Composite Thin Films. Mater. Sci. Forum 2005, 475-479, 3897-3900. [CrossRef]

69. Thukkaram, M.; Cools, P.; Nikiforov, A.; Rigole, P.; Coenye, T.; Van Der Voort, P.; Du Laing, G.; Vercruysse, C.; Declercq, H.; Morent, R.; et al. Antibacterial activity of a porous silver doped $\mathrm{TiO}_{2}$ coating on titanium substrates synthesized by plasma electrolytic oxidation. Appl. Surf. Sci. 2020, 500, 144235. [CrossRef] 